\title{
DISCURSO DO EXMO. SR. PROFESSOR MINISTRO JOSÉ CARLOS MOREIRA ALVES, EM RECEPÇÃO AO NOVO DIRETOR
}

\author{
José Carlos Moreira Alves \\ Professor Catedrático da Faculdade de Direito da \\ Universidade de São Paulo e \\ Ministro do Supremo Tribunal Federal
}

Minhas Senhoras e Meus Senhores.

A quem, como eu, se encontra na fase final de longa carreira universitária, e quem o imponderável do destino forçou, por ter sido alçado à Suprema Corte deste País, se encontre afastado do convívio desta Faculdade, em cujo corpo docente ingressou, ainda moço, então como catedrático faz quase 35 anos, é extremamente desvanecedor ter sido lembrado para saudar este jovem e brilhante professor que, nesta sessão, é empossado no honroso cargo de Diretor da Faculdade de Direito da Universidade de São Paulo, as tradicionais Arcadas do Largo de São Francisco, a que tanto deve a ciência jurídica pátria.

Lembro-me de que conheci Eduardo Marchi em Roma, no início da década de oitenta do século que já passou, quando ele freqüentava, havia pouco que se bacharelara, o Curso de Pós-Graduação da Faculdade de Direito da Universidade de Roma I - "La Sapienza", na área de Direito Romano. Nos vários dias que passei na Cidade Eterna para participar de congresso jurídico, tivemos estreito contato, o que me permitiu reconhecer nele, pela cultura que já possuía e pela dedicação aos estudos, uma esplêndida promessa de cultor do Direito.

Não me enganei. Em breve, a promessa se transformaria em realidade.

De feito, em 1984, obtém o título de doutor em Direito Romano pela já referida Faculdade italiana, titulo que, em junho de 1986, é revalidado pela Universidade de São Paulo, é aprovado, com distinção, no concurso para a livre docência também de Direito Romano. A seguir, em maio de 1988, classifica-se em primeiro lugar em concurso de ingresso na carreira docente junto ao Departamento de Direito Civil. Ainda nesse ano, galga a posição de professor adjunto. Em 1992 a 1994, como bolsista da Fundação Alexander von Humboldt, desenvolve, no Instituto Leopold Wenger da Faculdade de Direito da Universidade de Munique, pesquisa sobre "os riscos da coisa fortuita nos contratos de compra e venda (periculum rei venditae)" De volta ao Brasil, conquista, em concuros realizado no final de 1995, a titularidade da cadeira de Direito Romano.

A obra científica que tem produzido, na área de sua especialização, segue a linha de trabalho que, nesse terreno, é trilhada pelos estudiosos em países como a Itália e a Alemanha: o exame direto das fontes para extrair delas, inclusive com a análise dos glossemas e das interpolações, a evolução do pensamento dos juristas 
romanos que se pode entrever, principalmente, das soluções por ela dadas, como juristas práticos, na aplicação do Direito. Isso se evidencia nas teses para os concursos de livre docente e de professor titular, que examinei de perto como membro de suas bancas examinadoras. Versam elas, respectivamente, a controvertida questão da existência, em Roma, da propriedade horizontal e os complexos problemas do pactum ut minus solvatur, o precedente romano da moderna concordata. Apesar de se tratar de matérias em que há abundante bibliografia produzida por eminentes romanistas, apresentam essas teses interpretações originais das fontes que a elas concernem. E igualmente não fogem dessa linha de orientação, os diversos artigos que tem publicado em revistas nacionais e estrageiras. É deste ano o excelente estudo que, sob o título "Considerações acerca da Aditio Mandatu Creditorum" integra os "Studi in Onore de Mario Talamanca" seu principal orientador no curso de pós-graduação na Itália.

Não é, porém, Eduardo Marchi homem voltado exclusivamente à pesquisa e ao ensino do Direito Romano.

Sua vocação de professor - e professor que se tem dediçado à formação de discípulos no culto do Direito Romano - o levou a escrever o magnífico "Guia de Metodologia Jurídica", editado no início deste ano, e que se destina, como salientado em sua introdução, "a servir como meio auxiliar na preparação, em geral, de um livro juridico" tomada essa expressão em seu sentido lato, para abarcar, também, a elaboração de artigos.

Mais. A par de suas várias atividades administrativas institucionais no âmbito específico desta Escola e da Universidade a que ela se integra - assim, exemplificativamente quanto a estas, as de membro das Comissões de Cooperação Internacional e do Conselho Central de Pesquisa da Pró-Reitoria de Pesquisa -, é conhecida sua preocupação com o destino destas Arcadas. Na oração que proferiu ao tomar posse no cargo de professor titular, depois de assumir o compromisso de, com idealismo, seriedade e dedicação, contribuir para que elas retomem sua vocação maior de formar não apenas advogados e juristas, mas também - na expressão dos Estatutos do Visconde de Cachoeira - "homens hábeis" para reger os destinos da Nação, alertou para a necessidade de que não permaneçam elas inertes, "como simples relicário de glórias fenecidas, repousando sobre os louros já colhidos no passado", mas de que mantenham a liderança na qualidade do ensino e da pesquisa, a exigir reformas de base, para as quais apresentou várias sugestões fundadas em seus estágios em Universidades estrangeiras.

Professor Eduardo Cesar Silveira Vita Marchi:

Por suas qualidades morais e intelectuais, pelo seu idealismo e perseverança, foi merecidamente escolhido, depois de integrar lista tríplice, para ocupar o cargo de Diretor desta Faculdade, de que nos orgulhamos de pertencer.

São esses atributos o penhor da confiança que em você depositam os seus colegas, na certeza do êxito que terá no desempenho da nova missão que o aguarda.

Salão Nobre da Faculdade de Direito do Largo São Francisco, agosto de 2002. 


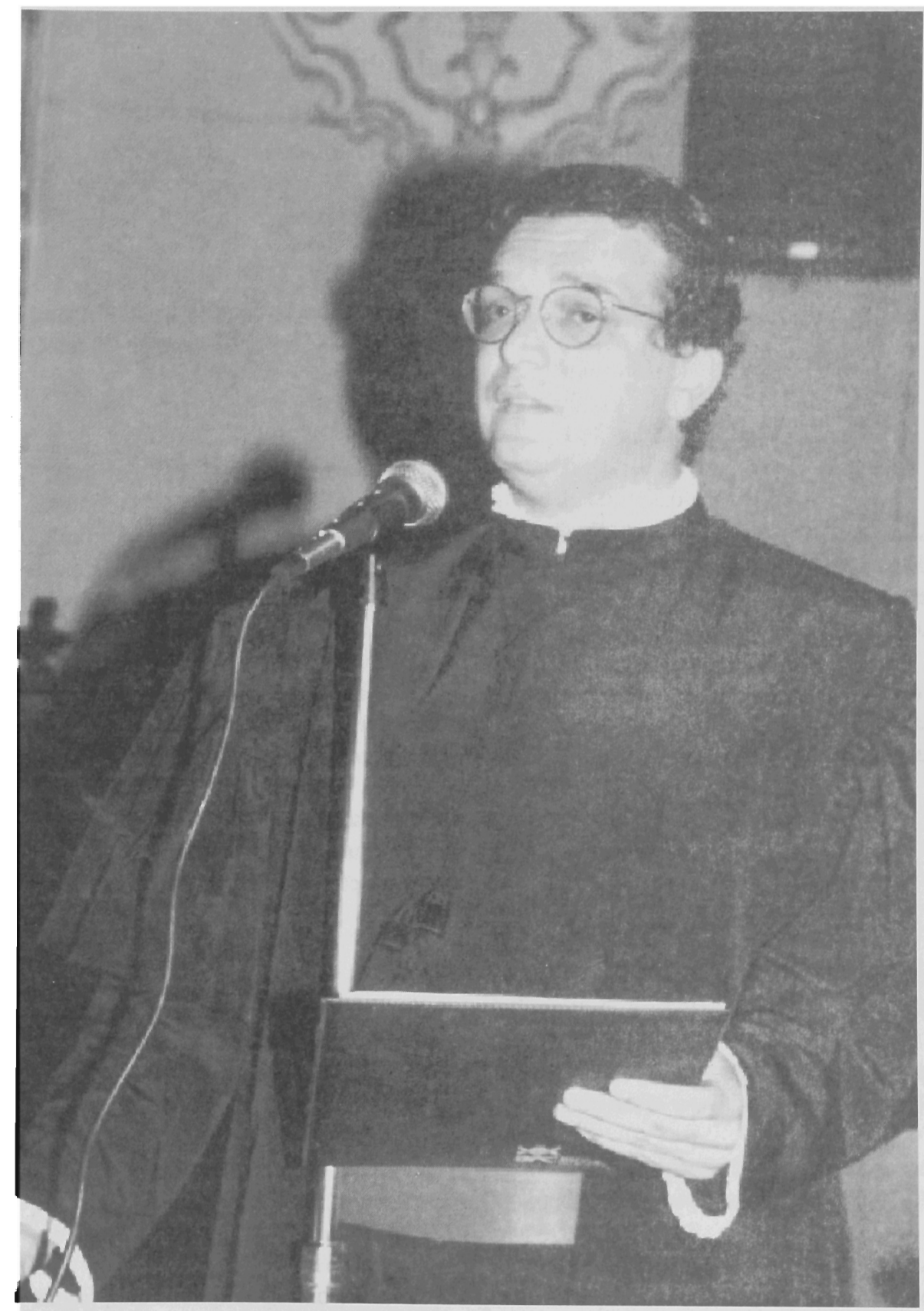

Professor Titular Eduardo Cesar Silveira Vita Marchi 